\title{
Imaging biotin trafficking in vivo with positron emission tomography
}

\section{Salvatore Bongarzone ${ }^{1}$, Teresa Sementa ${ }^{1}$, Joel Dunn ${ }^{1}$, Jayanta Bordoloi ${ }^{1}$, Kavitha Sunassee $^{1}$, Philip J. Blower ${ }^{1}$ and Antony Gee ${ }^{1}$}

${ }^{1}$ School of Biomedical Engineering \& Imaging Sciences, King's College London, King's Health Partners, St Thomas' Hospital, London, SE1 7EH, United Kingdom.

\section{SUPPORTING INFORMATION}

\section{Table of Contents}

Radiochemistry

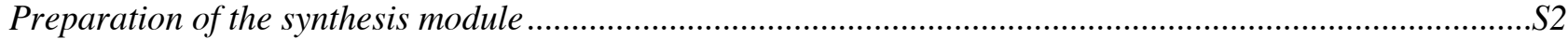

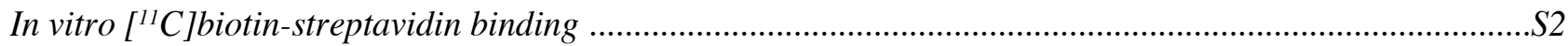

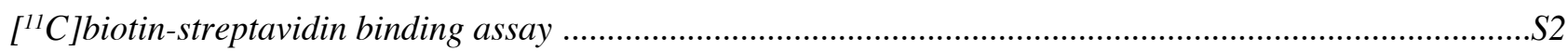

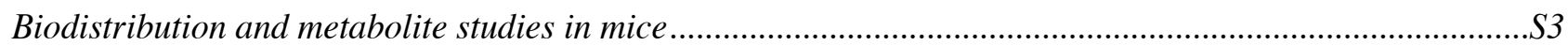

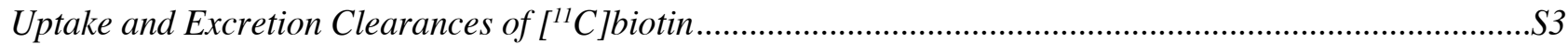

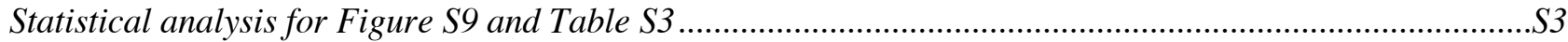

Figure S1: Schematic diagram of the automated synthesis of $\left[{ }^{11}\right.$ C]biotin .................................................... 4

Figure S2 Radio-HPLC radiochromatogram of formulated $\left[{ }^{11} C\right]$ biotin on analytical HPLC ........................S4

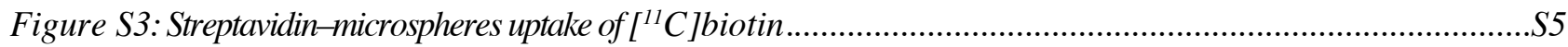

Figure S4. Schematic illustration of the PET/CT image acquisition of intravenous (IV) and orogastric gavage $(O G)$ administration of formulation $A$ and $\left[{ }^{I} C\right.$ C biotin ....................................................................S5

Figure S5: Time Activity curves of male and female mice receiving $\left[{ }^{I l} \mathrm{C}\right]$ biotin $I V$. ...................................S6

Figure S6 Correlation of blood radioactivity concentration from in vivo PET images versus ex vivo biodistribution. S6

Figure S7 Logan equation and Logan plots of kidney, liver, BAT and brain of groups A1-A3 ...............................S7

Figure S8 Patlak equation and Patlak plots of BAT and brain of groups A1-A3.................................................S 8

Figure S9: Biodistribution of radio activity after injection of $\left[{ }^{11} \mathrm{C}\right]$ biotin in mice ..........................................S9

Figure S10: Time Activity curves of female mice receiving $\left[{ }^{11} \mathrm{C}\right]$ biotin $O G$. ..............................................S9

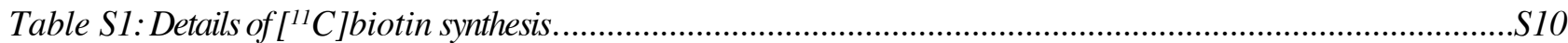

Table S2: Details of $\left[{ }^{11} \mathrm{C}\right]$ biotin formulation administered to animal groups..........................................................S10

Table S3: Tissue/Blood Ratio for groups A1-A3 ....................................................................................... 11

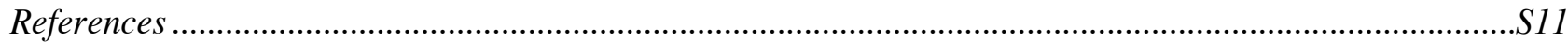




\section{Radiochemistry}

Biotin, 1,8-Diazabicyclo[5.4.0]undec-7-ene (DBU), tributylphosphine $\left(\mathrm{PBu}_{3}\right)$, di-tert-butyl azodicarboxylate (DBAD), dry acetonitrile $(\mathrm{MeCN})$, phosphate buffered saline tablets were obtained commercially from SigmaAldrich. (2S,3S,4R)-Cis-5-(3,4-Diaminotetrahydro-2-thienyl)valeric acid (diamino biotin) was obtained commercially from Insight Biotechnology.

\section{Preparation of the synthesis module}

The E\&Z E \& Z Eurotope GmbH (Berlin, Germany) "modular-lab" system was configured according to a $\left[{ }^{11} \mathrm{C}\right]$ biotin synthesis sequence program (Figure S1). In this configuration, two Peltier reactor modules (PRM), which allows temperature control from $-40^{\circ} \mathrm{C}$ to $+150^{\circ} \mathrm{C}$, was used. These reactors are equipped temperature and radioactivity sensors and a reactor camera. The reactions were carried out in an oven-dried vials (KX Microwave Vials, 2-5 mL) and crimp caps (Fisherbrand, centre hole with $3.0 \mathrm{~mm}$ PTFE seal aluminium silver $20 \mathrm{~mm}$, part \# 10132712). All the lines used to permit the flow of gases were PTFE tubing (length: 10-20 cm, ouside diameter: $0.79 \times 0.4$ in., inside diameter: $1 / 32 \times 0.16$ in.). $\mathrm{A}_{2} \mathrm{O}_{5}$ trap and one-way valve (BRAUN, normally closed backcheck valve, part \#415062) were placed before Vial A. An ascarite trap consisting of a cartridge (Biosys Solutions Ltd, Fritted Empty MiniSpeed Cartridges, part \# 2447) filled with ascarite (SigmaAldrich, 1310-73-2) and a Tedlar Gas Sampling Bags were placed after vial B to trap unreacted carbon-11 carbon dioxide $\left(\left[{ }^{11} \mathrm{C}\right] \mathrm{CO}_{2}\right)$. Transfers were controlled by the automatic switching of the in-line three-way valves on the modules. All processes are remotely controlled by a computer employing the dedicated modularlab software interface from E\&Z. At the end of radiosyntheis (after the complete decay of radioactivity), the system was cleaned by filling the reagent vials with sterile water, then acetonitrile, and lastly by a stream of helium. Cleaned and oven-dried vials and new tubing were used every time before starting a new $\left[{ }^{11} \mathrm{C}\right]$ biotin batch production. Parts after preparative HPLC (i.e. valves, preparative sample loop, product outlet tubing, PTFE tubing) were replaced or cleaned using water and acetonitrile.

\section{In vitro $\left[{ }^{11} \mathrm{C}\right]$ biotin-streptavidin binding}

To a $100 \mu \mathrm{L}$ suspension of streptavidin magnetic particles was added $400 \mu \mathrm{L}$ of a solution containing $150 \mathrm{mM}$ of $\mathrm{NaCl}$ and $10 \mathrm{mM}$ PBS (pH 7.4) in test tubes (1.5 mL). The streptavidin magnetic particles and supernatant were separated by SureBeads Magnetic Rack (Bio-Rad Laboratories, 1614916). The streptavidin magnetic particles were washed three times with $500 \mu \mathrm{L}$ of buffer. After the wash the streptavidin magnetic particles were incubated for 5 minutes at $25{ }^{\circ} \mathrm{C}$ with $\left[{ }^{11} \mathrm{C}\right]$ biotin in PBS $(0.56 \mathrm{nmol}$ of biotin, NBA), vehicle (PBS solution, no- $\left[{ }^{11} \mathrm{C}\right]$ biotin-added) and $0.1 \mathrm{mM}\left[{ }^{11} \mathrm{C}\right]$ biotin in PBS (biotin added). The streptavidin magnetic particles and supernatant were separated, and the streptavidin magnetic particles washed three times with PBS solution. The radioactivity content in all the tubes was measured using an automated well counter. Streptavidin binding was calculated as the percentage of the total radioactivity bound to the streptavidin magnetic particles after the washing. Control experiments were performed by replacing the streptavidin magnetic particles with solvent buffer.

\section{$\left[{ }^{11} \mathrm{C}\right]$ biotin-streptavidin binding assay}

Avidin and streptavidin have a strong avidity for biotin. The large association constant of the streptavidinbiotin interaction (10-15 M) has driven the use of radiolabeled biotin to track streptavidin in preclinical and clinical setting. $\left[{ }^{11} \mathrm{C}\right]$ biotin was assayed for streptavidin binding by mixing the radiolabeled compound with streptavidin magnetic beads for 10 minutes at room temperature. After separating the supernatant and washing the beads, it was found that $95.4 \pm 0.6 \%$ of $\left[{ }^{11} \mathrm{C}\right]$ biotin bound specifically to the immobilized streptavidin 
(Figure S3). Incubation with excess of unlabelled biotin reduced $\left[{ }^{11} \mathrm{C}\right]$ biotin retention to background level $(0.5$ $\pm 0.4 \%)$.

\section{Biodistribution and metabolite studies in mice}

Biodistribution studies were performed to the group of animals receiving $\left[{ }^{11} \mathrm{C}\right]$ biotin IV. Tissues including brain, cerebellum, heart, lungs, stomach, liver, spleen, small intestine, kidneys, thigh bone and eyes were excised. Blood was also collected. All samples were weighed, and radioactivity content measured using an automated well counter with a standard dilution of $\left[{ }^{11} \mathrm{C}\right]$ biotin. Counts were decay-corrected and the $\%$ of injected dose/gram of tissue (\%ID/g) calculated (Figure S9).

The urine was analysed with a Thin Layer Chromatography (TLC) plate and a mobile phase of butanol/acetic acid/water $(4: 1: 1 \mathrm{v} / \mathrm{v} / \mathrm{v})$. The plate was dried and exposed to phosphor imaging plates for 20 minutes and then scanned in a Typhoon 8600 phosphorimager (GE Healthcare). This analytical method has been reported by McCormick et al. which is able to separate biotin $\left(\mathrm{R}_{\mathrm{f}}=0.82\right)$, bisnorbiotin $\left(\mathrm{R}_{\mathrm{f}}=0.72\right)$ and biotin sulfoxide $\left(\mathrm{R}_{\mathrm{f}}=0.62\right)$ in the urine. ${ }^{1}$

\section{Uptake and Excretion Clearances of $\left[{ }^{11} \mathrm{C}\right]$ biotin}

Hepatic, renal, BAT, brain uptake clearances ( $\left.\mathrm{CL}_{\text {uptake, liver }}, \mathrm{CL}_{\text {uptake,kidney }}, \mathrm{CL}_{\text {uptake,BAT }}, \mathrm{CL}_{\text {uptake,brain }}\right)$ of $\left[{ }^{11} \mathrm{C}\right]$ biotin were measured from 0.3 to 4 min after tracer injection using the previously described integration plot method $^{2-6}$ and the following equation:

$$
\frac{C_{\text {tissue }, t}}{C_{\text {blood }, t}}=C L_{\text {uptake }} \frac{A U C_{\text {blood }, t}}{C_{\text {blood }, t}}+c
$$

where $\mathrm{C}_{\text {tissue, }}$ is the amount of radioactivity per gram tissue in liver, kidney, BAT, brain at time $\mathrm{t}$, and $\mathrm{C}_{\text {blood,t }}$ is the radioactivity concentration in the left ventricle of the heart at time $\mathrm{t}$. $\mathrm{AUC}_{\text {blood,t }}$ represents the area under the concentration-time curve in the left ventricle of the heart from time 0 to time $t$.

\section{Statistical analysis for Figure S9 and Table S3}

Biodistribution data and organ to blood data were analysed in SPSS (IBM SPSS Statistics, Version 24.0). using a linear mixed model to explore main and interaction effects of group and organ. Post hoc pairwise tests corrected for multiple comparisons were performed to explore differences between groups in the different organs following significant group and organ interaction effects $(\mathrm{p}<0.05)$. 


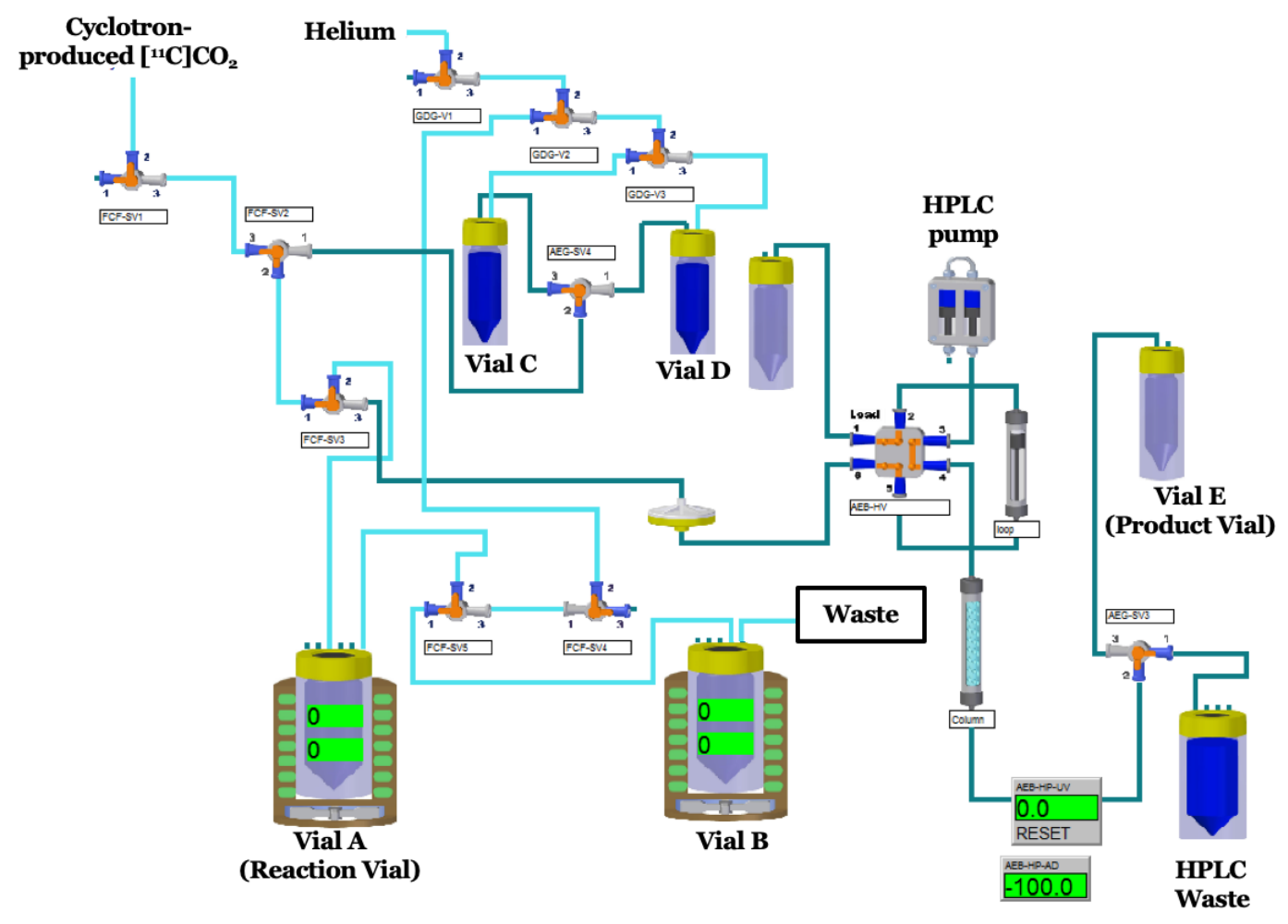

Figure S1: Schematic diagram of the automated synthesis of $\left[{ }^{11} \mathrm{C}\right] \mathrm{biotin}$.
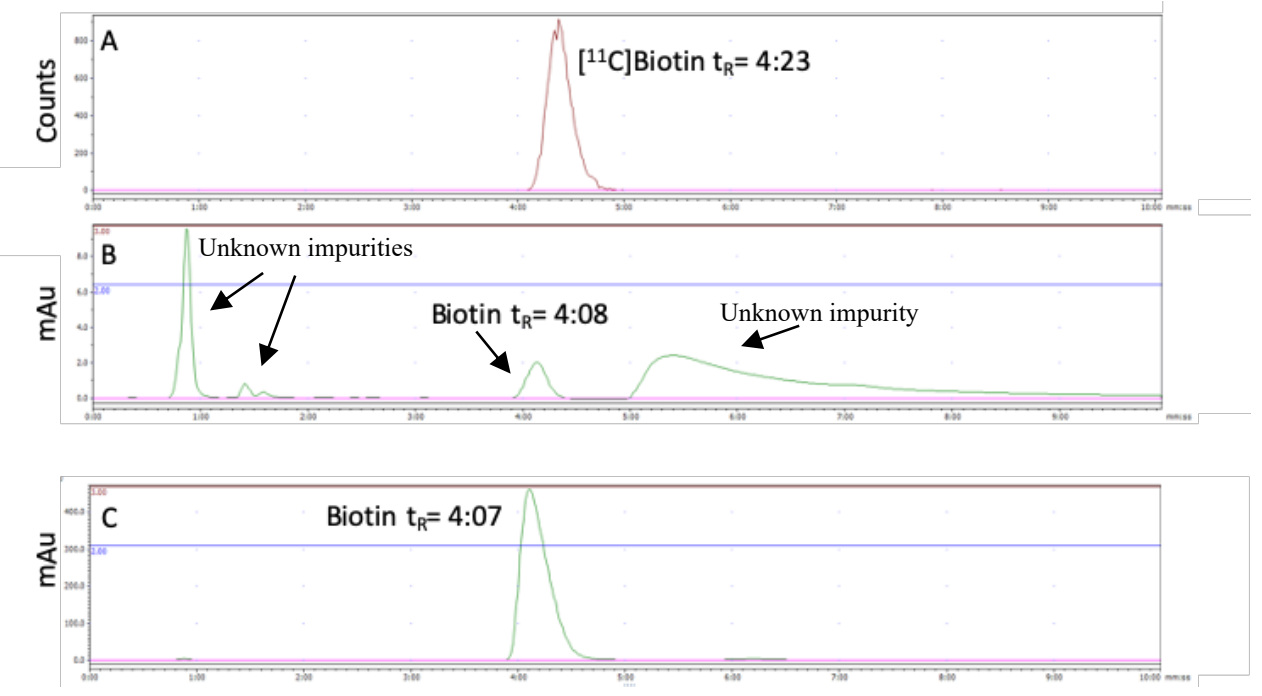

Figure S2 Radio-HPLC radiochromatogram of formulated $\left[{ }^{11} \mathrm{C}\right]$ biotin on analytical HPLC.

A Radio-HPLC radiochromatogram $\left[{ }^{11} \mathrm{C}\right]$ biotin (retention time $\left(\mathrm{t}_{\mathrm{R}}\right)=4$ minutes and 23 seconds) $\mathrm{B}$ ) UVchromatogram of formulated $\left[{ }^{1} \mathrm{C}\right]$ biotin $\left(t_{R}=4\right.$ minutes and 08 seconds) - UV detector $(\lambda=210 \mathrm{~nm})$. The difference between UV peaks and radioactivity peaks is 15 seconds and is in the range of delay of this instrument ( 15 seconds). C) UV chromatogram of biotin ( $t_{R}=4$ minutes and 08 seconds). 


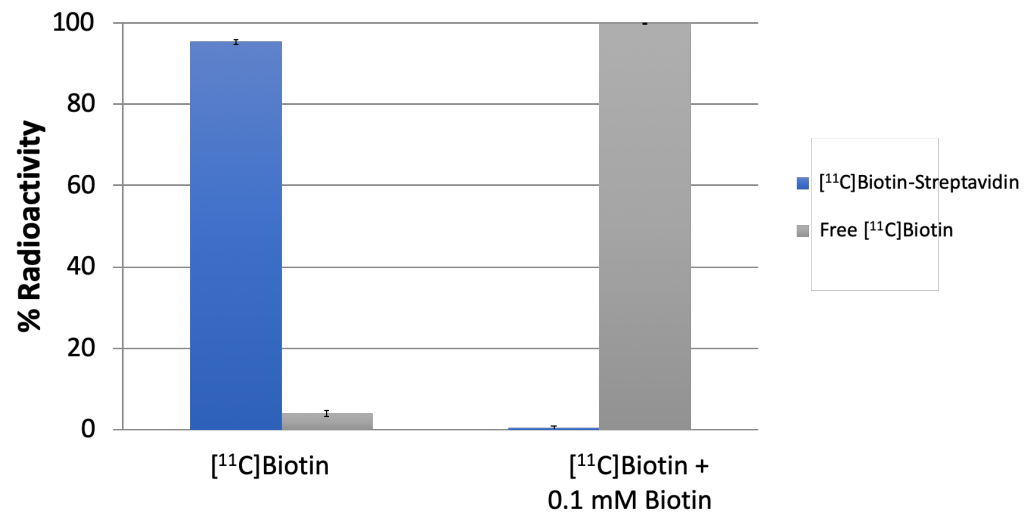

\section{Figure S3: Streptavidin-microspheres uptake of $\left[{ }^{11} \mathrm{C}\right]$ biotin.}

$\left[{ }^{11} \mathrm{C}\right]$ Biotin was incubated with superparamagnetic particles covalently coupled to streptavidin in the presence of vehicle or biotin $(0.1 \mathrm{mM})$. Blue bars indicated the $\%$ of $\left[{ }^{11} \mathrm{C}\right]$ biotin bound to the streptavidin magnetic beads. Grey bars indicated the $\%$ of $\left[{ }^{11} \mathrm{C}\right]$ biotin found in solution.

$\mathbf{A}$

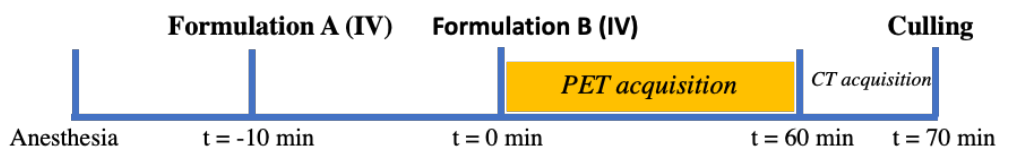

\begin{tabular}{|l|l|l|l|}
\hline $\begin{array}{l}\text { Group } \\
\text { name }\end{array}$ & Formulation A & Formulation B & Gender \\
\hline A1 (NBC) & Vehicle, IV & {$\left[{ }^{11}\right.$ C]Biotin, IV } & Female \\
\hline A2 (NBC) & Vehicle, IV & {$\left[{ }^{11}\right.$ C]Biotin, IV } & Male \\
\hline A3 (BC) & Biotin, IV & {$\left[{ }^{11}\right.$ C]Biotin, IV } & Female \\
\hline
\end{tabular}

B

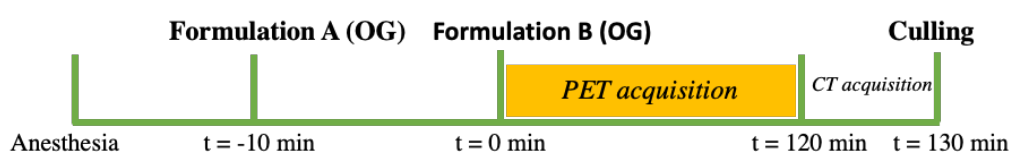

\begin{tabular}{|l|l|l|l|}
\hline $\begin{array}{l}\text { Group } \\
\text { name }\end{array}$ & Formulation A & Formulation B & Gender \\
\hline B1 (NBC) & Vehicle, OG & {$\left[{ }^{11}\right.$ C $]$ Biotin, OG } & Female \\
\hline B2 (BC) & Biotin, OG & {$\left[{ }^{11}\right.$ C]Biotin, OG } & Female \\
\hline
\end{tabular}

Figure S4. Schematic illustration of the PET/CT image acquisition of intravenous (IV) and orogastric gavage (OG) administration of formulation $A$ and $\left[{ }^{11} \mathrm{C}\right]$ biotin.

Formulation A: $2.5 \%$ ethanol in PBS (groups A1, A2 and B1) or biotin $(5 \mathrm{mg} / \mathrm{Kg}$ ) dissolved in $2.5 \%$ ethanol in PBS (groups A3 and B2). 
A
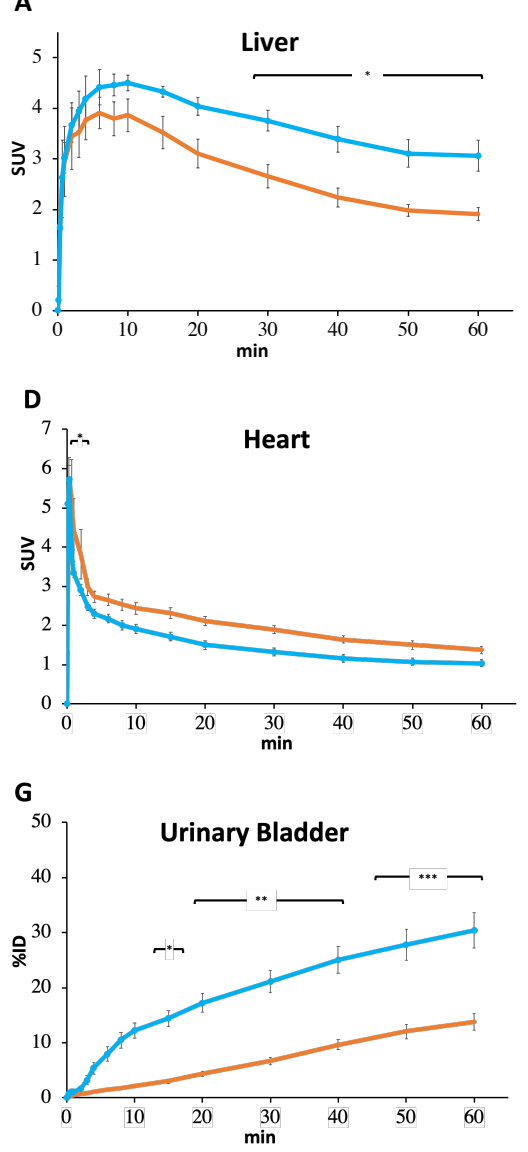

B
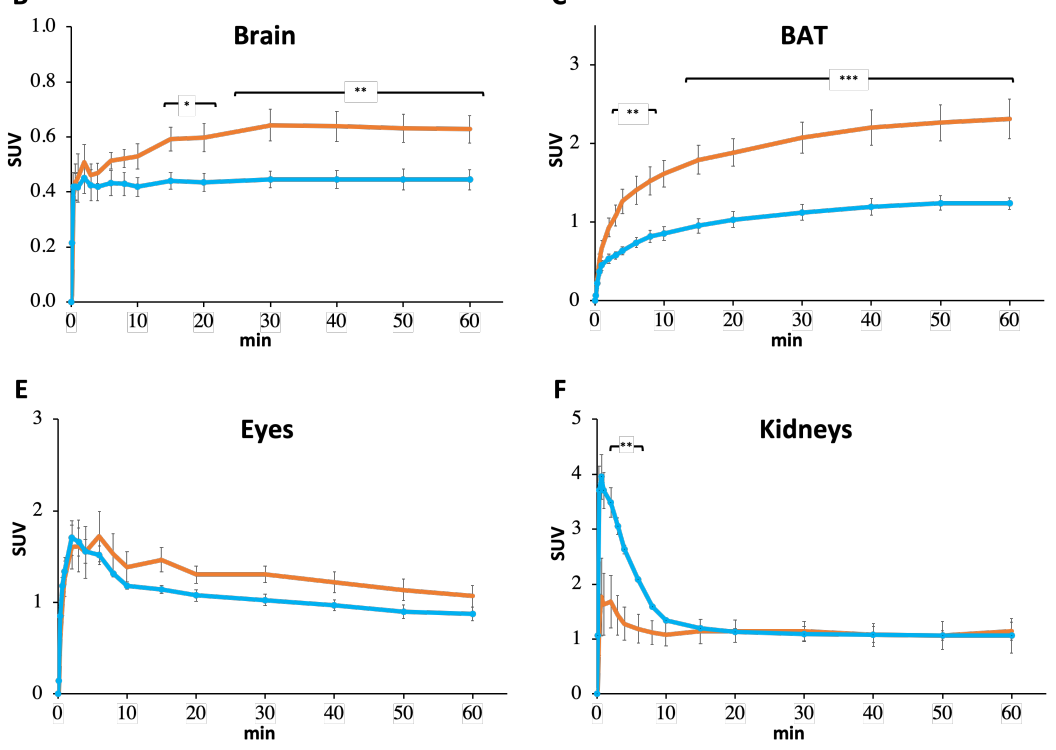

C

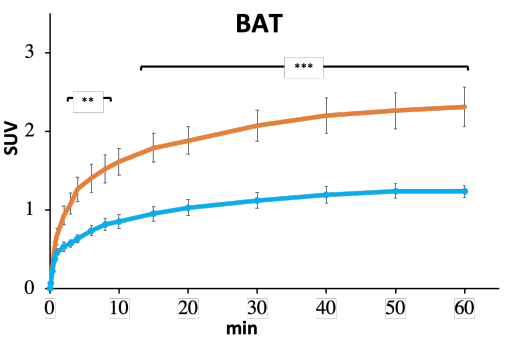

Figure S5: Time Activity curves of male and female mice receiving $\left[{ }^{11} \mathrm{C}\right] \mathrm{biotin}$ IV.

Time-SUV profile (0-60 minutes) of liver $(\mathbf{A})$, brain $(\mathbf{B})$, BAT $(\mathbf{C})$, heart $(\mathbf{D})$, eyes $(\mathbf{E})$, kidneys $(\mathbf{F})$ in female (orange line, group A1) and male (blue line, group A2) NBC mice. The radioactivity of urinary bladder (G) is expressed as $\%$ of ID. Data are the mean \pm SEM. Note that the $y$-scale (SUV) varies between the different tissues.

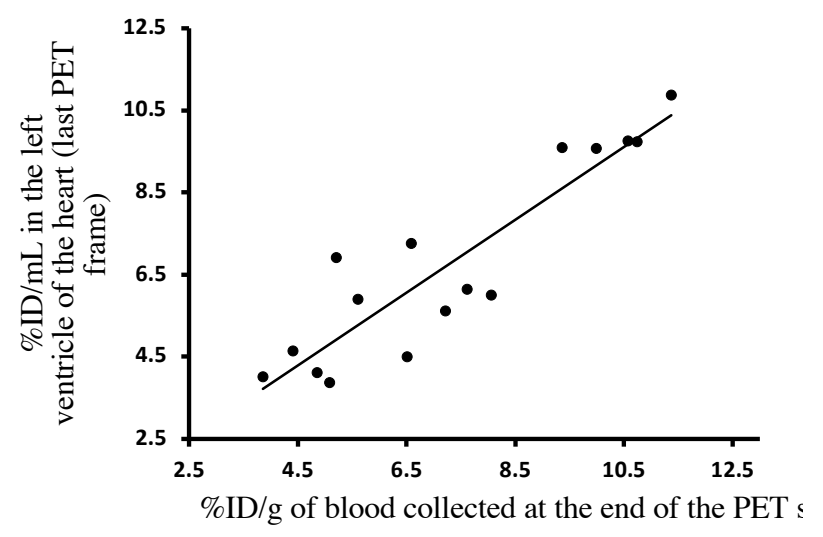

Figure S6 Correlation of blood radioactivity concentration from in vivo PET images versus ex vivo biodistribution.

Correlation of radioactivity concentration $(\% \mathrm{ID} / \mathrm{g})$ in the left ventricle of the heart measured in the last PET time frame (50-60 $\mathrm{min})$ with radioactivity concentration $((\% \mathrm{ID} / \mathrm{g})$ in venous blood collected at the end of the PET scan measured in a gamma counter. Solid line represents linear regression fit $(r=$ Pearson correlation coefficient $=0.91, \mathrm{P}$ value $<0.0001)$. 


$$
\frac{A U C_{t i s s u e, t}}{C_{t i s s u e, t}}=V_{T} \frac{A U C_{b l o o d, t}}{C_{t i s s u e, t}}+q
$$
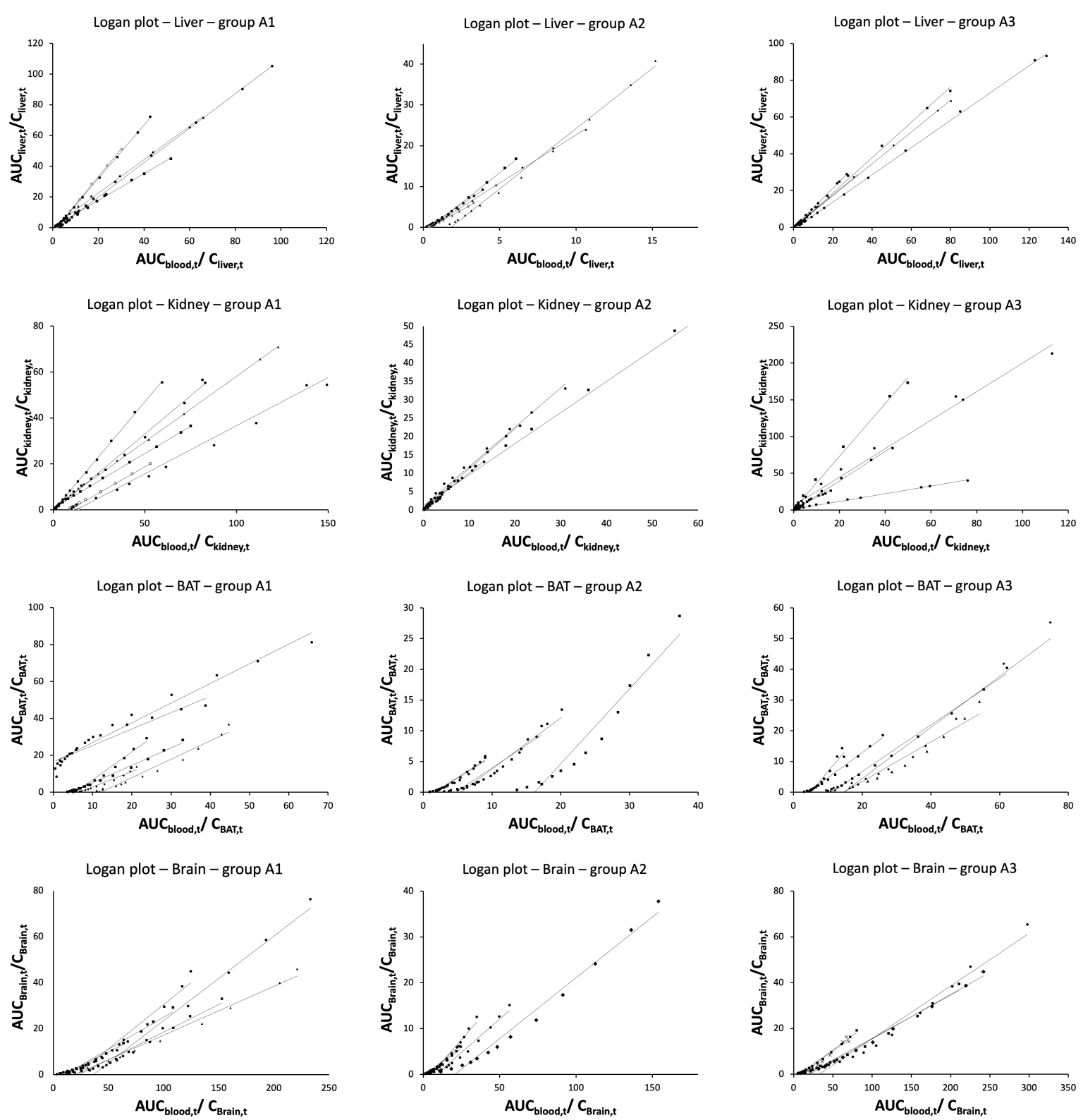

Figure S7 Logan equation and Logan plots of kidney, liver, BAT and brain of groups A1-A3. 


$$
\frac{C_{t i s s u e, t}}{C_{b l o o d, t}}=K_{i} \frac{A U C_{b l o o d, t}}{C_{b l o o d, t}}+c
$$
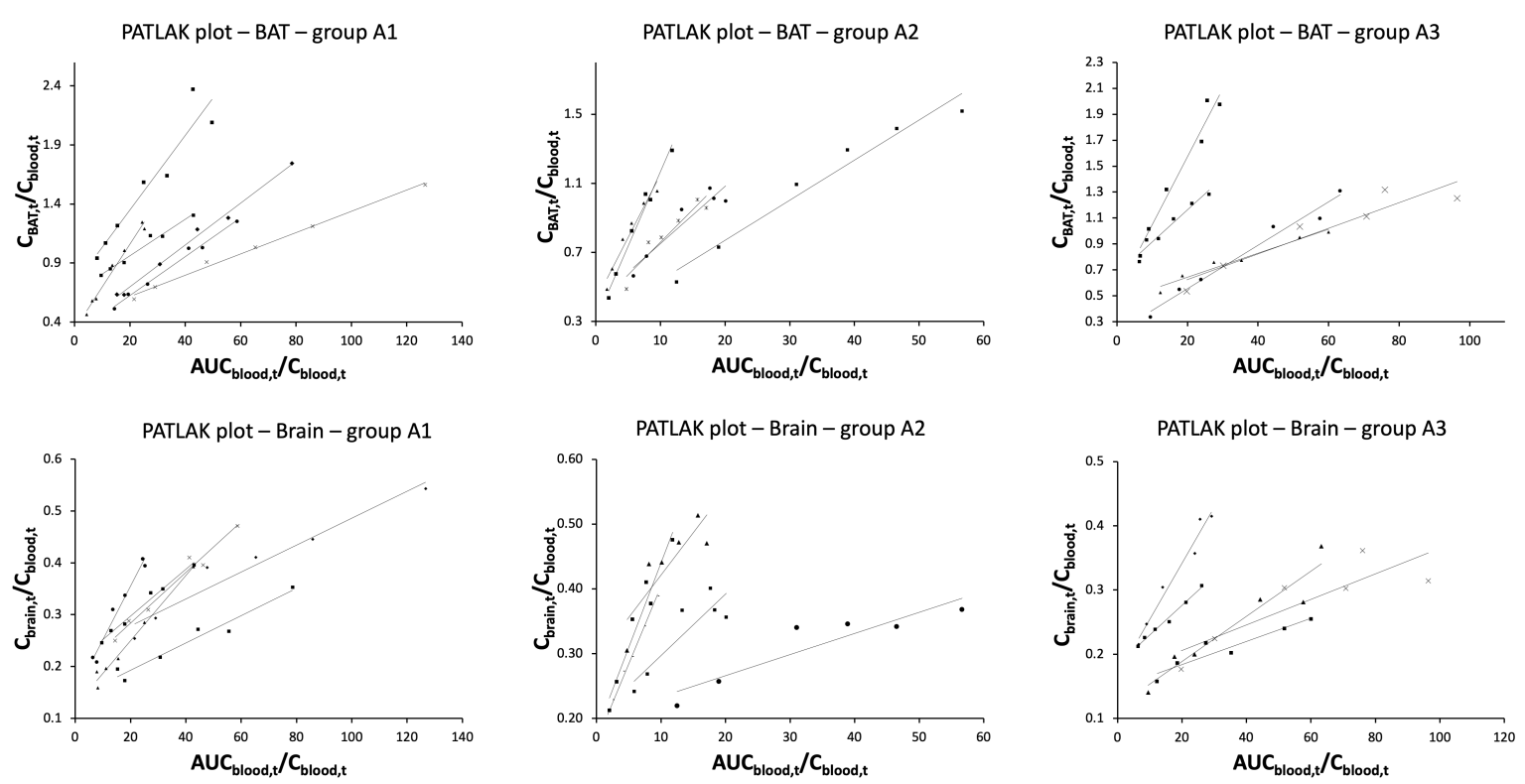

Figure S8 Patlak equation and Patlak plots of BAT and brain of groups A1-A3. 


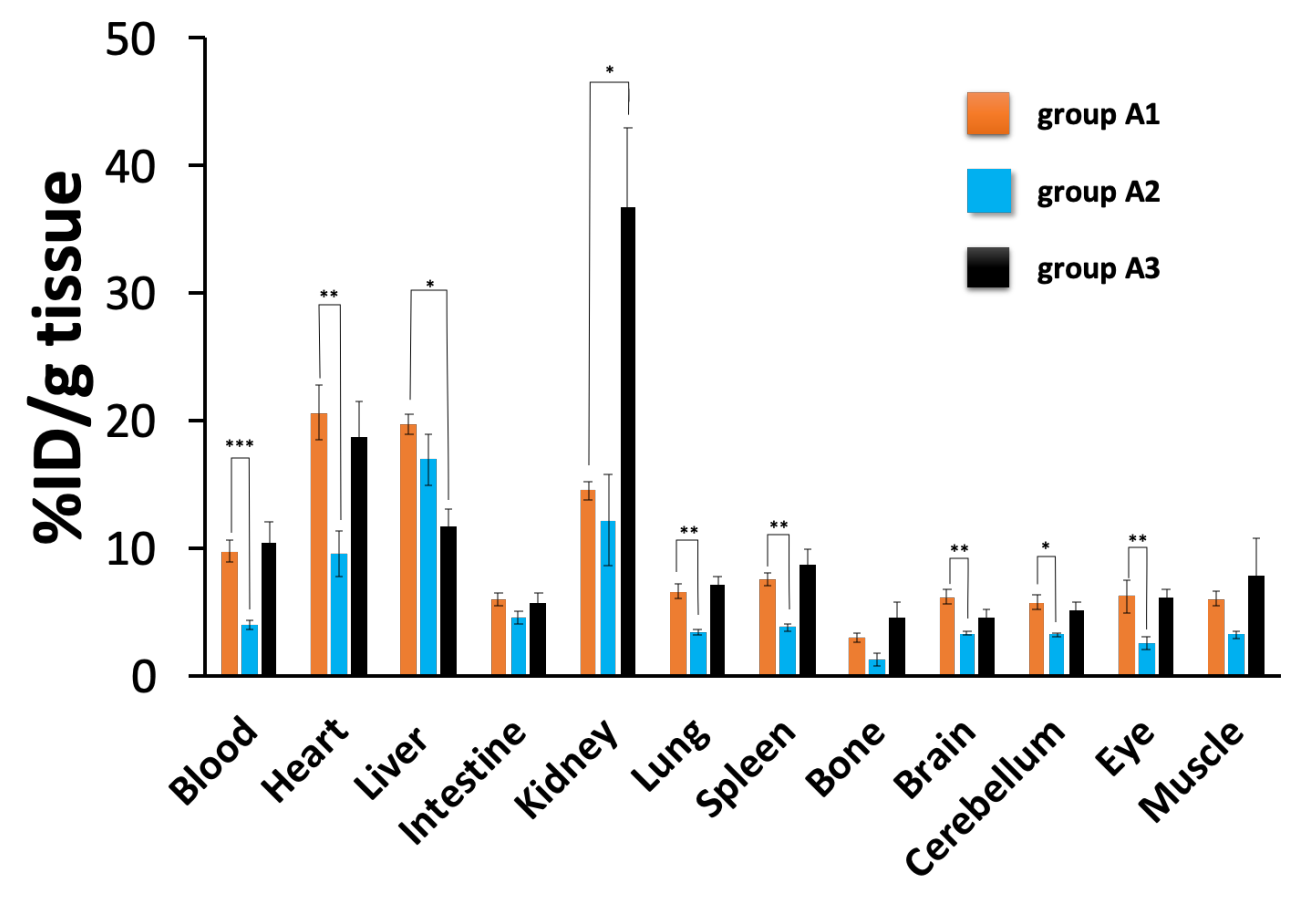

Figure S9: Biodistribution of radio activity after injection of $\left[{ }^{11} \mathrm{C}\right] \mathrm{biotin}$ in mice.

Biodistribution results at 70 minutes (normalized to a $20 \mathrm{~g}$ mouse) post-injection of $\left[{ }^{11} \mathrm{C}\right]$ biotin in female NBC mice (orange, group A1, $\mathrm{n}=6$ ), male $\mathrm{NBC}$ mice (blue, group A2, $\mathrm{n}=5$ ) and female $\mathrm{BC}$ mice (black, group A3, $\mathrm{n}=5$ ). Data are expressed as $\% \mathrm{ID} / \mathrm{g}$, mean \pm SEM. Data of groups A2 and A3 compared to control group A1 were indicated with $(*)$ for $\mathrm{p}<0.05,(* *)$ for $\mathrm{p}<0.01$, and $(* * *)$ for $\mathrm{p}<0.001$.
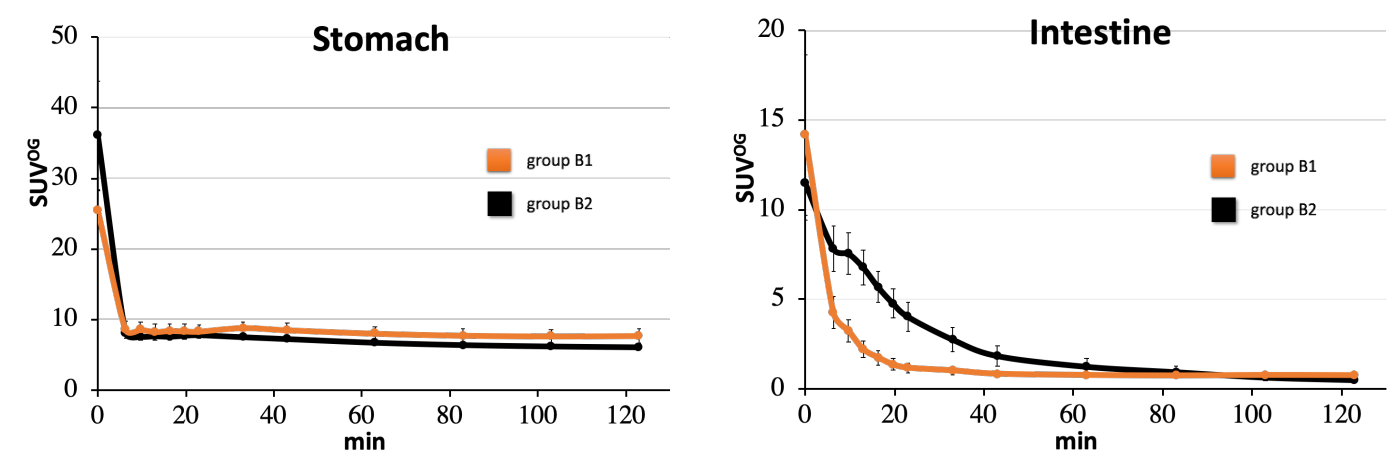

Figure S10: Time Activity curves of female mice receiving $\left[{ }^{11} \mathrm{C}\right]$ biotin OG.

Time-SUV profile (0-60 minutes) of stomach (A) and intestine (B) in NBA female (orange line, group B1) and BC male (black line, group B2) mice. Data are the mean \pm SEM. 
Table S1: Details of $\left[{ }^{11} \mathrm{C}\right]$ biotin synthesis.

\begin{tabular}{lc}
\hline $\begin{array}{l}\text { Cyclotron-delivered }\left[{ }^{11} \mathbf{C}\right] \mathbf{C O}_{2} \\
\text { radioactivity }\end{array}$ & $5.9 \pm 0.3 \mathrm{GBq}$ \\
$\mathbf{n}$ & 26 \\
$\mathbf{A}_{\mathbf{m}}$ at EOD & $7 \pm 1 \mathrm{GBq} / \mu \mathrm{mol}$ \\
$\begin{array}{l}\text { Activity yield - non decay } \\
\text { corrected }\end{array}$ & $6 \pm 1 \%$ \\
Isolated RCY & $19 \pm 2 \%$ \\
Radiochemical purity $(\mathbf{R C P})$ & $>99 \%$ \\
Radioactivity in 200 $\boldsymbol{\mu L}$ at EOS & $18 \pm 2 \mathrm{MBq}$ \\
Production time from EOD & $32 \pm 1 \mathrm{minutes}$ \\
\hline
\end{tabular}

Table S2: Details of $\left[{ }^{11} \mathrm{C}\right]$ biotin formulation administered to animal groups.

\begin{tabular}{|c|c|c|c|c|c|}
\hline Group & A1 & A2 & A3 & B1 & B2 \\
\hline Administration of $\left[{ }^{11} \mathrm{C}\right]$ biotin & IV & IV & IV & OG & OG \\
\hline $\begin{array}{l}\text { Administration of vehicle or } \\
\text { biotin }\end{array}$ & $\begin{array}{l}\text { IV } \\
\text { (vehicle) }\end{array}$ & $\begin{array}{l}\text { IV } \\
\text { (vehicle) }\end{array}$ & $\begin{array}{l}\text { IV } \\
\text { (biotin)* }\end{array}$ & $\begin{array}{l}\text { OG } \\
\text { (vehicle) }\end{array}$ & $\begin{array}{l}\text { OG } \\
\text { (biotin)* }\end{array}$ \\
\hline Gender & Female & Male & Female & Female & Female \\
\hline Number of animals & 6 & 5 & 5 & 5 & 5 \\
\hline Weight (g) & $17 \pm 1$ & $24 \pm 1$ & $17 \pm 1$ & $20 \pm 1$ & $20 \pm 1$ \\
\hline$A_{m}$ at EOD & $5.8 \pm 1.1$ & $7.5 \pm 0.6$ & $7.1 \pm 2.0$ & $7.7 \pm 1.4$ & $6.9 \pm 2.0$ \\
\hline $\begin{array}{l}A_{m} \text { at start of PET imaging } \\
\text { study }\end{array}$ & $0.5 \pm 0.1$ & $0.7 \pm 0.2$ & $0.7 \pm 0.3$ & $0.8 \pm 0.2$ & $0.8 \pm 0.2$ \\
\hline $\begin{array}{l}\text { Time from EOD to start of } \\
\text { PET Imaging study }\end{array}$ & $68 \pm 5$ & $69 \pm 7$ & $71 \pm 5$ & $68 \pm 7$ & $61 \pm 2$ \\
\hline $\begin{array}{l}\mu \mathrm{g} \text { of biotin in the }\left[{ }^{11} \mathrm{C}\right] \text { biotin } \\
\text { formulation }\end{array}$ & $1.6 \pm 0.4$ & $1.6 \pm 0.2$ & $1.7 \pm 0.6$ & $1.8 \pm 0.3$ & $1.7 \pm 0.5$ \\
\hline$\mu \mathrm{g} / \mathrm{kg}$ of biotin administered & $98 \pm 28$ & $67 \pm 9$ & $97 \pm 35$ & $94 \pm 16$ & $83 \pm 21$ \\
\hline Activity administered (MBq) & $3.3 \pm 0.5$ & $6.5 \pm 1.6$ & $3.0 \pm 0.8$ & $8.3 \pm 2.2$ & $5.1 \pm 1.1$ \\
\hline
\end{tabular}

${ }^{*}$ Groups $\mathrm{A} 3$ and $\mathrm{B} 2$ received $5 \mathrm{mg} / \mathrm{kg}$ of biotin 10 minutes before the administration of $\left[{ }^{11} \mathrm{C}\right]$ biotin. 
Table S3: Tissue/Blood Ratio for groups A1-A3.

\begin{tabular}{lccc}
\hline & Group A1 & Group A2 & Group A3 \\
\hline Heart & $2.1 \pm 0.7$ & $2.4 \pm 1.1$ & $1.8 \pm 0.9$ \\
Liver & $2.0 \pm 0.5$ & $4.2 \pm 1.7^{* * *}$ & $1.1 \pm 0.6^{*}$ \\
Intestine & $0.6 \pm 0.2$ & $1.1 \pm 0.3^{* * *}$ & $0.6 \pm 0.3$ \\
Kidney & $1.5 \pm 0.4$ & $3.0 \pm 2.8$ & $3.6 \pm 2.3$ \\
Lung & $0.7 \pm 0.2$ & $0.8 \pm 0.2$ & $0.7 \pm 0.3$ \\
Spleen & $0.8 \pm 0.2$ & $0.9 \pm 0.2$ & $0.8 \pm 0.4$ \\
Bone & $0.3 \pm 0.1$ & $0.3 \pm 0.3$ & $0.4 \pm 0.3$ \\
Brain & $0.6 \pm 0.2$ & $0.8 \pm 0.2$ & $0.4 \pm 0.2$ \\
Cerebellum & $0.6 \pm 0.2$ & $0.8 \pm 0.2^{* *}$ & $0.5 \pm 0.2$ \\
Eye & $0.6 \pm 0.4$ & $0.7 \pm 0.4$ & $0.6 \pm 0.3$ \\
Muscle & $0.6 \pm 0.2$ & $0.8 \pm 0.2$ & $0.8 \pm 0.7$ \\
\hline
\end{tabular}

Data of groups A2 and A3 compared to control group A1 were indicated with $\left(^{*}\right)$ for $\mathrm{p}<0.05,\left(^{* *}\right)$ for $\mathrm{p}<$ 0.01 , and $(* * *)$ for $\mathrm{p}<0.001$

\section{References}

(1) Lee, H. M.; Wright, L. D.; McCormick, D. B. Metabolism of carbonyl-labeled ${ }^{14}$ C-biotin in the rat. J Nutr 1972, 102, 1453-1463.

(2) Traxl, A.; Wanek, T.; Mairinger, S.; Stanek, J.; Filip, T.; Sauberer, M.; Muller, M.; Kuntner, C.; Langer, $\mathrm{O}$. Breast cancer resistance protein and p-glycoprotein influence in vivo disposition of ${ }^{11} \mathrm{C}$-erlotinib. J. Nucl. Med. 2015, 56, 1930-1936.

(3) Takashima, T.; Wu, C.; Takashima-Hirano, M.; Katayama, Y.; Wada, Y.; Suzuki, M.; Kusuhara, H.; Sugiyama, Y.; Watanabe, Y. Evaluation of breast cancer resistance protein function in hepatobiliary and renal excretion using PET with ${ }^{11} \mathrm{C}-\mathrm{SC}-62807$. J. Nucl. Med. 2013, 54, 267-276.

(4) Takashima, T.; Nagata, H.; Nakae, T.; Cui, Y.; Wada, Y.; Kitamura, S.; Doi, H.; Suzuki, M.; Maeda, K.; Kusuhara, H.; Sugiyama, Y.; Watanabe, Y. Positron emission tomography studies using (15R)-16-m$\left[{ }^{11} \mathrm{C}\right]$ tolyl-17,18,19,20-tetranorisocarbacyclin methyl ester for the evaluation of hepatobiliary transport. $J$. Pharmacol. Exp. Ther. 2010, 335, 314-323.

(5) Shingaki, T.; Hume, W. E.; Takashima, T.; Katayama, Y.; Okauchi, T.; Hayashinaka, E.; Wada, Y.; Cui, Y.; Kusuhara, H.; Sugiyama, Y.; Watanabe, Y. Quantitative evaluation of mMate1 function based on minimally invasive measurement of tissue concentration using PET with $\left[{ }^{11} \mathrm{C}\right]$ metformin in mouse. Pharm. Res. 2015, 32, 2538-2547.

(6) Takano, A.; Kusuhara, H.; Suhara, T.; Ieiri, I.; Morimoto, T.; Lee, Y. J.; Maeda, J.; Ikoma, Y.; Ito, H.; Suzuki, K.; Sugiyama, Y. Evaluation of in vivo p-glycoprotein function at the blood-brain barrier among MDR1 gene polymorphisms by using ${ }^{11} \mathrm{C}$-verapamil. J. Nucl. Med. 2006, 47, 1427-1433. 